\title{
Metanephric Diverticulum
}

National Cancer Institute

\section{Source}

National Cancer Institute. Metanephric Diverticulum. NCI Thesaurus. Code C34207.

An outgrowth arising from each mesonephric duct during the 5th week of embryonic development, which gives rise to the renal collecting ducts, calyces, pelvis and ureters, and, together with the metanephric blastema, will give rise to the permanent kidney. 